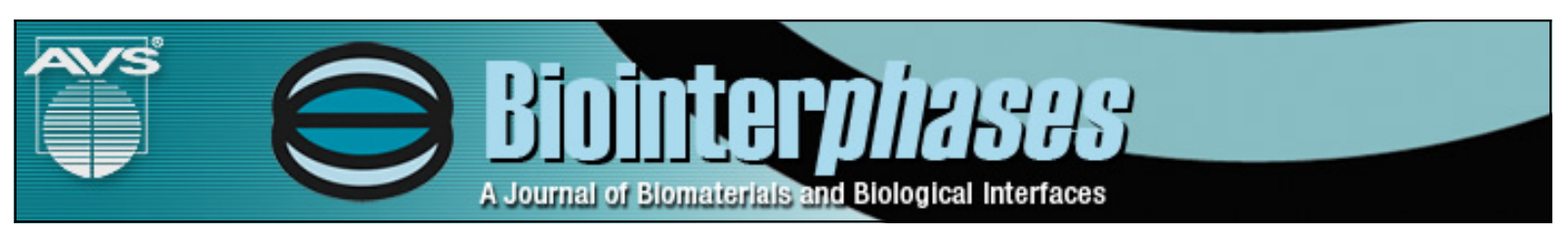

\title{
Fibrinogen adsorption and platelet adhesion to silica surfaces with stochastic nanotopography
}

Megan S. Lord, John M. Whitelock, Anne Simmons, Rachel L. Williams, and Bruce K. Milthorpe

Citation: Biointerphases 9, 041002 (2014); doi: 10.1116/1.4900993

View online: http://dx.doi.org/10.1116/1.4900993

View Table of Contents: http://scitation.aip.org/content/avs/journal/bip/9/4?ver=pdfcov

Published by the AVS: Science \& Technology of Materials, Interfaces, and Processing

\section{Articles you may be interested in}

Effect of micropatterned TiO2 nanotubes thin film on the deposition of endothelial extracellular matrix: For the purpose of enhancing surface biocompatibility

Biointerphases 10, 04A302 (2015); 10.1116/1.4928304

Toll like receptor 2/1 mediated platelet adhesion and activation on bacterial mimetic surfaces is dependent on src/Syk-signaling and purinergic receptor P2X1 and P2Y12 activation

Biointerphases 9, 041003 (2014); 10.1116/1.4901135

Effects of human fibronectin and human serum albumin sequential adsorption on preosteoblastic cell adhesion Biointerphases 9, 029008 (2014); 10.1116/1.4867598

Combinatorial growth of oxide nanoscaffolds and its influence in osteoblast cell adhesion

J. Appl. Phys. 111, 102810 (2012); 10.1063/1.4714727

Selective fibronectin adsorption against albumin and enhanced stem cell attachment on helium atmospheric pressure glow discharge treated titanium

J. Appl. Phys. 109, 124701 (2011); 10.1063/1.3599885 


\title{
Fibrinogen adsorption and platelet adhesion to silica surfaces with stochastic nanotopography
}

\author{
Megan S. Lord ${ }^{\mathrm{a})}$ and John M. Whitelock \\ Graduate School of Biomedical Engineering, University of New South Wales, Sydney, New South Wales 2052, \\ Australia \\ Anne Simmons \\ School of Mechanical and Manufacturing Engineering, University of New South Wales, Sydney, \\ New South Wales 2052, Australia \\ Rachel L. Williams \\ Department of Eye and Vision Science, Institute of Ageing and Chronic Disease, University of Liverpool, \\ Liverpool L69 3GA, United Kingdom \\ Bruce K. Milthorpe \\ Faculty of Science, University of Technology, Sydney, Broadway, New South Wales 2007, Australia
}

(Received 10 September 2014; accepted 23 October 2014; published 4 November 2014)

In this study, the effect of surface nanoscale roughness on fibrinogen adsorption and platelet adhesion was investigated. Nanorough silica surfaces with a low level of surface roughness $(10 \mathrm{~nm}$ $R_{r m s}$ ) were found to support the same level of fibrinogen adsorption as the planar silica surfaces, while nanorough silica surfaces with higher levels of surface roughness $\left(15 \mathrm{~nm} \mathrm{R}_{\mathrm{rms}}\right)$ were found to support significantly less fibrinogen adsorption. All surfaces analyzed were found to support the same level of platelet adhesion; however, platelets were rounded in morphology on the nanorough silica surfaces while platelets were spread with a well-developed actin cytoskeleton on the planar silica. Unique quartz crystal microbalance with dissipation monitoring (QCM-D) responses was observed for the interactions between platelets and each of the surfaces. The QCM-D data indicated that platelets were more weakly attached to the nanorough silica surfaces compared with the planar silica. These data support the role of surface nanotopography in directing platelet-surface interactions even when the adsorbed fibrinogen layer is able to support the same level of platelet adhesion. (C) 2014 American Vacuum Society. [http://dx.doi.org/10.1116/1.4900993]

\section{INTRODUCTION}

Blood interactions with biomaterial surfaces are initiated by protein adsorption, which influences subsequent blood cell interactions with materials and ultimately the hemocompatibility of materials. Insights into the role of surface properties in regulating protein adsorption and subsequent platelet receptor binding events are crucial to develop advanced materials capable of modulating platelet adhesion and activation events at the blood-material interface and hence long term function. Surface properties including topography and chemistry are known to influence the extent of protein adsorption, which proteins adsorb and their conformation. ${ }^{1,2}$ Studies have shown that the surface topography of an underlying substrate influences protein adsorption that precedes cell behavior such as adhesion, orientation, and proliferation. ${ }^{3}$ Nanoscale surface topography has previously been shown to alter adsorbed protein conformation compared to planar surfaces; $;^{4-7}$ however, the extent of conformational change is dependent on both the surface nanofeatures and the protein under investigation. Researchers have focused on the effect of ordered nanostructures on protein adsorption including grooves ${ }^{8}$ and pits, ${ }^{9}$ while other groups have investigated the effect of

\footnotetext{
${ }^{a)}$ Electronic mail: m.lord@unsw.edu.au
}

stochastically rough surfaces, ${ }^{4-6,10}$ although each differ in their reported effect due to the different surface topographies investigated.

Fibrinogen is one of the most abundant soluble extracellular matrix proteins present in blood and likely to adsorb to most surfaces. ${ }^{11-14}$ Fibrinogen and other serum proteins, such as fibronectin and von Willebrand factor, mediate platelet adhesion and aggregation via direct interaction with platelet receptors. ${ }^{15-17}$ Surface bound fibrinogen has been implicated in mediating the adhesion of platelets to synthetic surfaces through the integrin $\alpha \operatorname{IIb} \beta 3 .{ }^{11}$ Platelet adhesion to fibrinogen via $\alpha \operatorname{IIb} \beta 3$ integrin involves the RGDS site on the $\mathrm{A} \alpha$ chain and a non-RGD dodecapeptide sequence in the $\gamma$ chain on fibrinogen. ${ }^{18}$ The few reports describing the effect of surface nanotopography on platelet adhesion indicate that this phenomenon is surface dependent. Platelet adhesion to nanorough titanium surfaces has been shown to be enhanced when precoated with fibrinogen. ${ }^{9}$ In contrast, vertically aligned multiwall carbon nanotubes resist platelet adhesion, ${ }^{19}$ and nanostructured poly(ethylene oxide) had no effect on platelet adhesion compared to planar controls. ${ }^{20}$ Recently, surface features in the order of several hundred nanometers with low aspect ratios have been found to experience lower fibrinogen adsorption and platelet adhesion compared to their high aspect ratio counterparts. ${ }^{7}$ 
In this study, the adsorption and conformation of a strongly anisotropic protein, fibrinogen, on stochastically nanorough silica surfaces, with varying surface roughness, and subsequent platelet interactions were investigated. The aim of this study was to further elucidate the effect of surface nanotopography on these interactions.

\section{EXPERIMENT}

Chemicals were purchased from Sigma-Aldrich (Castle Hill, Australia) unless stated otherwise.

\section{A. Surface fabrication}

Gold quartz crystal microbalance (QCM) crystals (QSX301, Q-Sense AB, Sweden) were covered with $0.32 \mathrm{~g} / \mathrm{l}$ aqueous dispersion of polycationic polymer, Zetag $^{\mathrm{TM}}$ (Ciba Specialty Chemicals Ltd., UK), a highly cross-linked copolymer of acrylamide (20\%) and quaternary dimethylaminoethylacrylate $(80 \%)$, for $10 \mathrm{~min}$ before rinsing with MilliQ water for $3 \mathrm{~min}$ and dried with nitrogen. The polycationic polymer was used to immobilize the silica nanoparticles onto the gold surface and generate the nanorough silica surfaces. The polymer-coated surfaces were covered with $30 \% \mathrm{w} / \mathrm{v}$ aqueous colloidal silica sols (W.R. Grace \& Co., UK) for $5 \mathrm{~min}$ to ensure attachment of the silica particles to the cationic polymer. Three types of silica sols were used with average particle diameters of 7, 14, and $21 \mathrm{~nm}$ (Ludox SM-30, HS-40, and TM-50, respectively). Substrates were again rinsed with MilliQ water for $3 \mathrm{~min}$ and dried with nitrogen. The silica-coated surfaces were then stored in a desiccator for at least $24 \mathrm{~h}$ before use. $\mathrm{SiO}_{2}$ coated gold (QSX303) QCM crystals (Q-Sense AB, Sweden) were used as planar silica.

\section{Surface characterization}

Surface topography was analyzed by atomic force microscopy (AFM) in tapping mode using the BioScope Catalyst AFM in air at a scan rate of $0.2 \mathrm{~Hz}$ and an aspect ratio of 1 . Scan sizes of $1 \mu \mathrm{m}$ were obtained using a $2 \mathrm{~nm}$ "ScanAsystAir+" AFM tip (Bruker, Australia). Three separate images were obtained for each sample and root-meansquare $(\mathrm{rms})$ surface roughness $\left(\mathrm{R}_{\mathrm{rms}}\right)$ was calculated. A Perkin Elmer Spotlight 400 Attenuated total reflectanceFourier transform infrared spectroscopy (ATR-FTIR) was used to measure the surface chemical structure of the silica surfaces with a penetration depth of $500 \mathrm{~nm}$. Spectra were recorded between 650 and $3500 \mathrm{~cm}^{-1}$.

\section{B. Quantification of protein adsorption}

Single protein solutions of human fibrinogen $(30 \mu \mathrm{g} / \mathrm{ml})$ and bovine serum albumin (BSA, $30 \mu \mathrm{g} / \mathrm{ml}$ ) were prepared in phosphate buffered saline (PBS), $p \mathrm{H}$ 7.4. Human plasma $(10 \% \mathrm{v} / \mathrm{v})$ in PBS was used as the complex protein solution.

Quantification of protein adsorption was carried out using a quartz crystal microbalance with dissipation monitoring (QCM-D, D300 model, Q-Sense AB, Sweden) in static mode at $37 \pm 0.1^{\circ} \mathrm{C}$. Surfaces were exposed to PBS and stable frequency $(f)$ and dissipation (D) measurements established. Test protein solutions were exposed to the surfaces for $60 \mathrm{~min}$ and then rinsed with PBS until consistent $f$ and D measurements were obtained. A minimum of three adsorption curves were recorded for each material for all test proteins, which were measured at the fundamental $f(\sim 5 \mathrm{MHz})$ as well as the third $(15 \mathrm{MHz})$, fifth $(25 \mathrm{MHz})$, and seventh (35 MHz) overtones. All solutions were passed through a $0.22 \mu \mathrm{m}$ filter and degassed at room temperature before use. Adsorbed mass estimates were obtained using the Voigt model and adjusted for the surface area measured by AFM.

Surfaces coated with fibrinogen were additionally treated with $0.1 \%(\mathrm{w} / \mathrm{v})$ casein to block remaining surface binding sites for $30 \mathrm{~min}$, rinsed with PBS until consistent $f$ and D measurements were obtained, incubated with an antifibrinogen antibody (5 $\mu \mathrm{g} / \mathrm{ml}$, clone 2C2-G7, IgG, Bio-Scientific Pty. Ltd., Gymea, Australia) prepared in $0.1 \%$ (w/v) casein for $30 \mathrm{~min}$ and rinsed with PBS until consistent $f$ and D measurements were obtained. Adsorbed antibody mass estimates were also obtained using the Voigt model. Control experiments were performed for nonspecific antibody binding to the fibrinogen coated surfaces with an antialbumin antibody (5 $\mu \mathrm{g} / \mathrm{ml}$, clone HSA-11, IgG, Sigma Aldrich, Castle Hill, Australia). The epitope for the antifibrinogen antibody, clone $2 \mathrm{C} 2-\mathrm{G} 7$, is able to recognize or sterically hinder regions of fibrinogen important for platelet aggregation.

Fibrinogen adsorption to the surfaces was also measured using biotinylated fibrinogen. $10 \mathrm{mM}$ EZ-link NHS-Biotin (Pierce Biotechnology, Australia) diluted in dimethylsulfoxide was added to $5 \mathrm{mg} / \mathrm{ml}$ fibrinogen in PBS and incubated in the dark for $2 \mathrm{~h}$ before separating the biotinylated proteins from excess biotin using a $10 \mathrm{kDa}$ microcon (BD, Australia) centrifuged at $13000 \mathrm{rpm}$ for $15 \mathrm{~min}$. Following a washing step with PBS, the solution was centrifuged for $15 \mathrm{~min}$ and washed six times before use. The final concentration of protein was measured using the Coomassie Blue Protein Assay (Pierce Biotechnology, Australia). Biotinylated fibrinogen was diluted to $30 \mu \mathrm{g} / \mathrm{ml}$ and exposed to the surfaces for 60 min followed by rinsing with PBS. The surfaces were then blocked with $0.1 \%(\mathrm{w} / \mathrm{v})$ casein for $30 \mathrm{~min}$ and rinsed with PBS. The bound biotinylated fibrinogen was detected with streptavidin-horseradish peroxidase (SA-HRP,GE Biosciences, Sydney, Australia, 1:500) for $30 \mathrm{~min}$ at $25^{\circ} \mathrm{C}$ using $2 \mathrm{mM} \quad 2,2^{\prime}$-azino-di-3-ethylbenzthiazoline sulfonic acid and $\mathrm{H}_{2} \mathrm{O}_{2}$ as chromogen in $50 \mathrm{mM}$ sodium citrate, $p \mathrm{H}$ 4.6. Absorbance values were measured at $405 \mathrm{~nm}$.

\section{Platelet isolation from human blood}

Platelets were harvested from human donors under ethics approval from the University of New South Wales. Blood was collected in acid citrate dextrose anticoagulant treated vacutainers. Platelet rich plasma was prepared by centrifugation of the blood at $350 \mathrm{~g}$ for $20 \mathrm{~min}$ at room temperature followed by careful removal of the upper platelet-rich layer. 
Platelet rich plasma was then centrifuged at $1200 \mathrm{~g}$ for $10 \mathrm{~min}$ to yield a platelet pellet with platelet poor plasma as the supernatant. The platelet pellet was resuspended in Tyrode's buffer $\left(1.8 \mathrm{mM} \mathrm{CaCl}_{2}, 1 \mathrm{mM} \mathrm{MgCl}_{2}, 2.7 \mathrm{mM} \mathrm{KCl}\right.$, $136.9 \mathrm{mM} \mathrm{NaCl}, 0.4 \mathrm{mM} \mathrm{NaH} \mathrm{PO}_{4}, 11.9 \mathrm{mM} \mathrm{NaHCO}_{3}$, and $5.6 \mathrm{mM}$ D-glucose) containing $0.1 \mathrm{U} / \mathrm{ml}$ apyrase and centrifuged again at $1200 \mathrm{~g}$ for $10 \mathrm{~min}$. The supernatant was discarded and the platelets resuspended in Tyrode's buffer, containing $0.1 \mathrm{U} / \mathrm{ml}$ apyrase, to a concentration of $2 \times 10^{7}$ platelets/ml based on haemocytometer counts.

\section{Platelet adhesion assays}

\section{Lactate dehydrogenase assay}

Quantification of platelets adhered to test surfaces was determined using an in vitro using a lactate dehydrogenase assay (LDH, TOX7 kit). ${ }^{21}$ This method is based on the reduction of NAD by the action of $\mathrm{LDH}$, which is a stable cytoplasmic enzyme present in cells. It is rapidly released into the lysing solution upon damage of the plasma membrane. The use of a toxicology assay kit allows quantification of the number of platelets as a function of the amount of LDH released.

Surfaces were exposed to BSA $(30 \mu \mathrm{g} / \mathrm{ml})$, human fibrinogen $(30 \mu \mathrm{g} / \mathrm{ml})$, or $10 \%(\mathrm{v} / \mathrm{v})$ human plasma for $1 \mathrm{~h}$ at $37^{\circ} \mathrm{C}$. All protein solutions were diluted in PBS. Wells were then blocked with $0.1 \%(\mathrm{w} / \mathrm{v}) \mathrm{BSA}$ in PBS for $2 \mathrm{~h}$ at $37^{\circ} \mathrm{C}$ to coat the remaining surface binding sites. Platelets $\left(1 \mathrm{ml}\right.$ of $2 \times 10^{7}$ platelets $/ \mathrm{ml}$ ) were incubated on the surfaces for $1 \mathrm{~h}$ at $37^{\circ} \mathrm{C}$. Test surfaces were rinsed twice with PBS (prewarmed $\left.37^{\circ} \mathrm{C}\right)$. Platelet suspension $\left(2 \times 10^{7}\right.$ platelets $/ \mathrm{ml}$ in Tyrodes buffer containing Apyrase) was added to each well and incubated for $1 \mathrm{~h}$. The platelet suspension was then removed from the wells and test surfaces were washed six times with PBS. Surfaces were moved to fresh wells to eliminate counting platelets adhered to the wells and a 1/10 lysis solution in PBS was added to each well and incubated at $37^{\circ} \mathrm{C}$ for $45 \mathrm{~min}$ to lyse the adhered platelets. A standard curve was generated in parallel using platelet concentrations in the range of $2 \times 10^{4}-2 \times 10^{7}$ platelets $/ \mathrm{ml}$. Equal volumes of platelet lysates $(50 \mu \mathrm{l})$ and LDH solution $(50 \mu \mathrm{l})$ were transferred to wells of a TCPS 96-well plate and incubated for $30 \mathrm{~min}$ at $37^{\circ} \mathrm{C}$. The absorbance was measured at $490 \mathrm{~nm}$ against a $650 \mathrm{~nm}$ reference using a microplate reader.

\section{Fluorescence microscopy}

Imaging of the actin cytoskeleton of platelets on the various surfaces was performed as described previously. ${ }^{22}$ Surfaces were exposed to BSA $(30 \mu \mathrm{g} / \mathrm{ml})$, human fibrinogen $(30 \mu \mathrm{g} / \mathrm{ml})$ or $10 \%(\mathrm{v} / \mathrm{v})$ human plasma for $1 \mathrm{~h}$ at $37^{\circ} \mathrm{C}$. All protein solutions were diluted in PBS. Wells were then blocked with $0.1 \%(\mathrm{w} / \mathrm{v}) \mathrm{BSA}$ in PBS for $2 \mathrm{~h}$ at $37^{\circ} \mathrm{C}$ to coat the remaining surface binding sites. Selected samples were subsequently incubated with antifibrinogen antibody $(5 \mu \mathrm{g} / \mathrm{ml}$, clone $2 \mathrm{C} 2-\mathrm{G} 7)$ diluted in $0.1 \%$ (w/v) BSA in PBS for $1 \mathrm{~h}$ at $37^{\circ} \mathrm{C}$ and then rinsed with PBS. Wells were then blocked with $0.1 \%(\mathrm{w} / \mathrm{v}) \mathrm{BSA}$ in $\mathrm{PBS}$ for $2 \mathrm{~h}$ at $37^{\circ} \mathrm{C}$. Platelets $\left(1 \mathrm{ml}\right.$ of $2 \times 10^{7}$ platelets $/ \mathrm{ml}$ in Tyrodes buffer containing Apyrase) were incubated on the surfaces for $1 \mathrm{~h}$ at $37^{\circ} \mathrm{C}$, either alone or in combination with antihuman GP IIb-IIIa receptor (integrin $\alpha \mathrm{IIb} \beta 3$ ) $\mathrm{F}(\mathrm{ab})$ fragment antibody (1 $\mu \mathrm{g} / \mathrm{ml}$, Abciximab, Eli Lily, Sydney, Australia). Platelets were fixed with $4 \%(\mathrm{w} / \mathrm{v})$ formaldehyde and $1 \%(\mathrm{w} / \mathrm{v}) \mathrm{su}-$ crose in PBS for $20 \mathrm{~min}$ at $37^{\circ} \mathrm{C}$ followed by permeabilization for $5 \mathrm{~min}$ at $4^{\circ} \mathrm{C}$ with $0.3 \mathrm{M}$ sucrose, $0.05 \mathrm{M} \mathrm{NaCl}$, $3 \mathrm{mM} \mathrm{MgCl}_{2}, 0.2 \mathrm{M} \mathrm{HEPES}, 0.5 \%$ (w/v) Triton X-100, $p \mathrm{H}$ 7.2. Wells were then blocked with $1 \%(\mathrm{w} / \mathrm{v}) \mathrm{BSA}$ in PBS for $5 \mathrm{~min}$ at $37^{\circ} \mathrm{C}$ followed by incubation with rhodaminephalloidin $(1: 100$ in $1 \%(\mathrm{w} / \mathrm{v})$ BSA in PBS, Life Technologies, Sydney, Australia) for $1 \mathrm{~h}$ at $37^{\circ} \mathrm{C}$. Samples were then washed twice with $0.5 \%$ (w/v) Tween-20 in PBS before imaging using a fluorescence microscope (Zeiss, Sydney, Australia). Quantitative analysis of the fluorescence microscope images was performed using a pixelated computer program (NIH ImageJ) to determine the number of adhered platelets for each condition.

\section{Quartz crystal microbalance assays}

Platelet interactions with protein coated surfaces were measured in a quartz crystal microbalance with dissipation monitoring (QCM-D) window chamber (QWiC 301, Q-Sense AB, Sweden) which was internally maintained at $37.0 \pm 0.1^{\circ} \mathrm{C}$ under static conditions. Planar silica or colloidal silica coated QCM crystals were mounted in the window chamber. PBS was injected into the chamber and allowed to stabilize before being removed and replaced with a solution in PBS of either bovine serum albumin $(30 \mu \mathrm{g} / \mathrm{ml})$, fibrinogen $(30 \mu \mathrm{g} / \mathrm{ml})$ or $10 \%(\mathrm{v} / \mathrm{v})$ human plasma which was allowed to adsorb for $1 \mathrm{~h}$. The chamber was then rinsed with PBS, allowing for $f$ and D stabilization. PBS was replaced with $0.1 \%$ (w/v) BSA in PBS and allowed to stabilize for $30 \mathrm{~min}$ before being replaced with $1 \mathrm{ml}$ of platelet suspension containing $2 \times 10^{7}$ platelets $/ \mathrm{ml}$ in Tyrode's buffer containing $0.1 \mathrm{U} / \mathrm{ml}$ apyrase. Platelet interactions with the protein coatings were monitored for $1 \mathrm{~h}$ after an initial thermal settling period of $10 \mathrm{~min}$. Additionally, selected protein coatings were exposed to platelets in the presence of anti- $\alpha \mathrm{IIb} \beta 3(2.5 \mu \mathrm{g} / \mathrm{ml}) \mathrm{Fab}$ fragment antibody. It is important to note that the Fab fragment antibodies do not support platelet aggregation, which would confound the results. Experiments were performed in triplicate with representative profiles presented. Platelet interaction measurements are presented as $\mathrm{D} f$ plots and were fitted to the Voigt model.

\section{E. Statistical analysis}

A two-way analysis of variance (ANOVA) was performed to compare multiple conditions. Results of $p<0.05$ were considered significant. Experiments were performed in triplicate and were repeated twice.

\section{RESULTS AND DISCUSSION}

\section{A. Surface characterization}

Surfaces were characterized by AFM in tapping mode to measure the root mean square surface roughness $\left(\mathrm{R}_{\mathrm{rms}}\right)$ 
TABLE I. Surface roughness of substrates characterized by AFM and the increase in surface area compared to planar $\mathrm{SiO}_{2}$ coated QCM crystals. Data presented as mean \pm standard deviation $(n=3)$. * indicates significant difference $(p<0.05)$ compared to planar silica and $* *$ indicates significant difference $(p<0.05)$ compared to $7 \mathrm{~nm}$ silica.

\begin{tabular}{lcc}
\hline \hline $\begin{array}{l}\text { Substrate coating } \\
\text { on QCM crystals }\end{array}$ & $\begin{array}{c}\text { Root mean square } \\
\text { roughness, } \mathrm{R}_{\mathrm{rms}}(\mathrm{nm})\end{array}$ & $\begin{array}{c}\text { Increase in surface area } \\
\text { compared to planar silica } \\
\text { coated QCM crystals }(\%)\end{array}$ \\
\hline Planar silica & $2.38 \pm 0.80^{* *}$ & - \\
$7 \mathrm{~nm}$ silica & $9.88 \pm 2.42^{*}$ & $12 \pm 5^{*}$ \\
$14 \mathrm{~nm}$ silica & $10.76 \pm 2.62^{* * *}$ & $15 \pm 6^{*}$ \\
$21 \mathrm{~nm}$ silica & $15.28 \pm 1.71^{* * * *}$ & $27 \pm 5^{* * *}$ \\
Zetag & $1.92 \pm 0.59^{* *}$ & - \\
\hline \hline
\end{tabular}

(Table I). The planar silica coated QCM-D crystals were found to have an $R_{r m s}$ of $2.38 \pm 0.80 \mathrm{~nm}$ while the surfaces generated using the 7,14 , and $21 \mathrm{~nm}$ silica nanoparticles exhibited a size-dependent increase in $\mathrm{Ra}$ of $9.88 \pm 2.42$, $10.76 \pm 2.62$, and $15.28 \pm 1.71 \mathrm{~nm}$, respectively. The surfaces that were generated using the silica nanoparticles exhibited a uniform surface topography [Fig. 1(a)] with a stochastic surface roughness as previously reported and nanoparticles that completely covered the polycationic layer. ${ }^{1}$ The planar silica surface was smooth with very few topographical features [Fig. 1(b)]. The corresponding increase in surface area for the surfaces generated using the 7,14 , and $21 \mathrm{~nm}$ silica nanoparticles resulted in an increase in surface area compared to the planar silica of $12 \pm 5 \%$, $15 \pm 6 \%$, and $27 \pm 5 \%$, respectively (Table I).

ATR-FTIR confirmed the presence of $\mathrm{SiO}_{2}$ with bands between 800 and $1260 \mathrm{~cm}^{-1}$ ascribed to the superposition of various $\mathrm{SiO}_{2}$ peaks including asymmetric vibration of $\mathrm{Si}-\mathrm{O}$ $\left(1090 \mathrm{~cm}^{-1}\right)$ and symmetric vibration of Si-O $\left(795 \mathrm{~cm}^{-1}\right)$ [Fig. 1(c)]. These peaks were present in the planar silica as well as the 7, 14, and $21 \mathrm{~nm}$ silica nanoparticles with no appreciable difference in intensity indicating that the surface chemistry of each of the silica surfaces was similar.

\section{B. Protein adsorption and conformation}

Fibrinogen adsorption onto each of the silica surfaces was investigated in real time using QCM-D (Fig. 2). Changes in frequency $(\Delta f)$ and dissipation $(\Delta \mathrm{D})$ measured by the QCM$\mathrm{D}$ were monitored over a period of $60 \mathrm{~min}$ exposure time to the fibrinogen and subsequent PBS rinses [Fig. 2(a)]. The $\Delta f$ values observed for fibrinogen adsorption onto each of the surfaces were similar throughout the measurement period while different $\Delta \mathrm{D}$ values were observed. Fibrinogen bound to the nanorough silica surfaces exhibited smaller $\Delta \mathrm{D}$ values than fibrinogen bound to the planar silica. Adsorption of fibrinogen onto each of the surfaces resulted in little change in $f$ measurements after PBS rinses for each of the surfaces indicating that the adsorption may be largely irreversible or that desorption was very slow. Changes in $\Delta f$ and $\Delta \mathrm{D}$ were used to estimate the mass of irreversibly adsorbed fibrinogen onto each of the surfaces. The Voigt model was used to estimate the mass of adsorbed fibrinogen as fibrinogen adsorption onto all of the surfaces under investigation was found to yield $\Delta \mathrm{D}$ values for all overtones greater than $1 \times 10^{-6}$, while very limited $f$ dependency was observed. Mass values derived from the Voigt model were adjusted for changes in surface area due to the surface roughness. There was significantly less fibrinogen adsorbed onto the $21 \mathrm{~nm}$ silica surface compared to the planar silica $(p<0.05)$, while there was no significant difference in the amount of fibrinogen bound to either the 7 or $14 \mathrm{~nm}$ silica surfaces or the Zetag surface compared to the planar silica [Fig. 2(b)]. Fibrinogen adsorption onto nanorough tantalum surfaces has previously been reported to increase with increasing surface roughness $^{23}$ to a larger extent than the corresponding increase in surface area. This was attributed to the whiskerlike protrusions deposited by the glancing angle deposition (GLAD) technique that created the nanorough surface
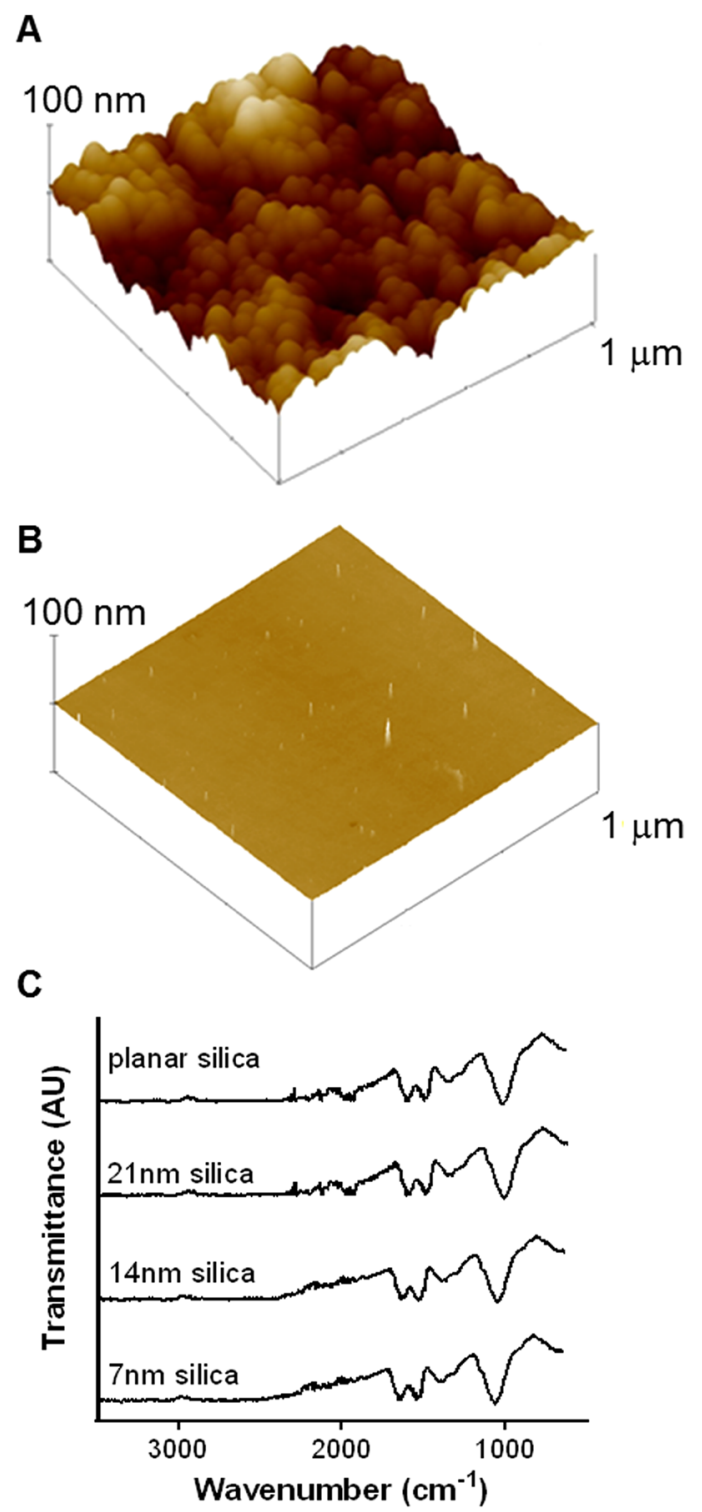

FIG. 1. AFM images of (a) $21 \mathrm{~nm}$ silica and (b) planar silica with a scan size of $1 \times 1 \mu \mathrm{m}^{2}$ and a vertical range of $100 \mathrm{~nm}$. (c) ATR-FTIR spectra of planar silica as well as 7,14 , and $21 \mathrm{~nm}$ silica surfaces. 

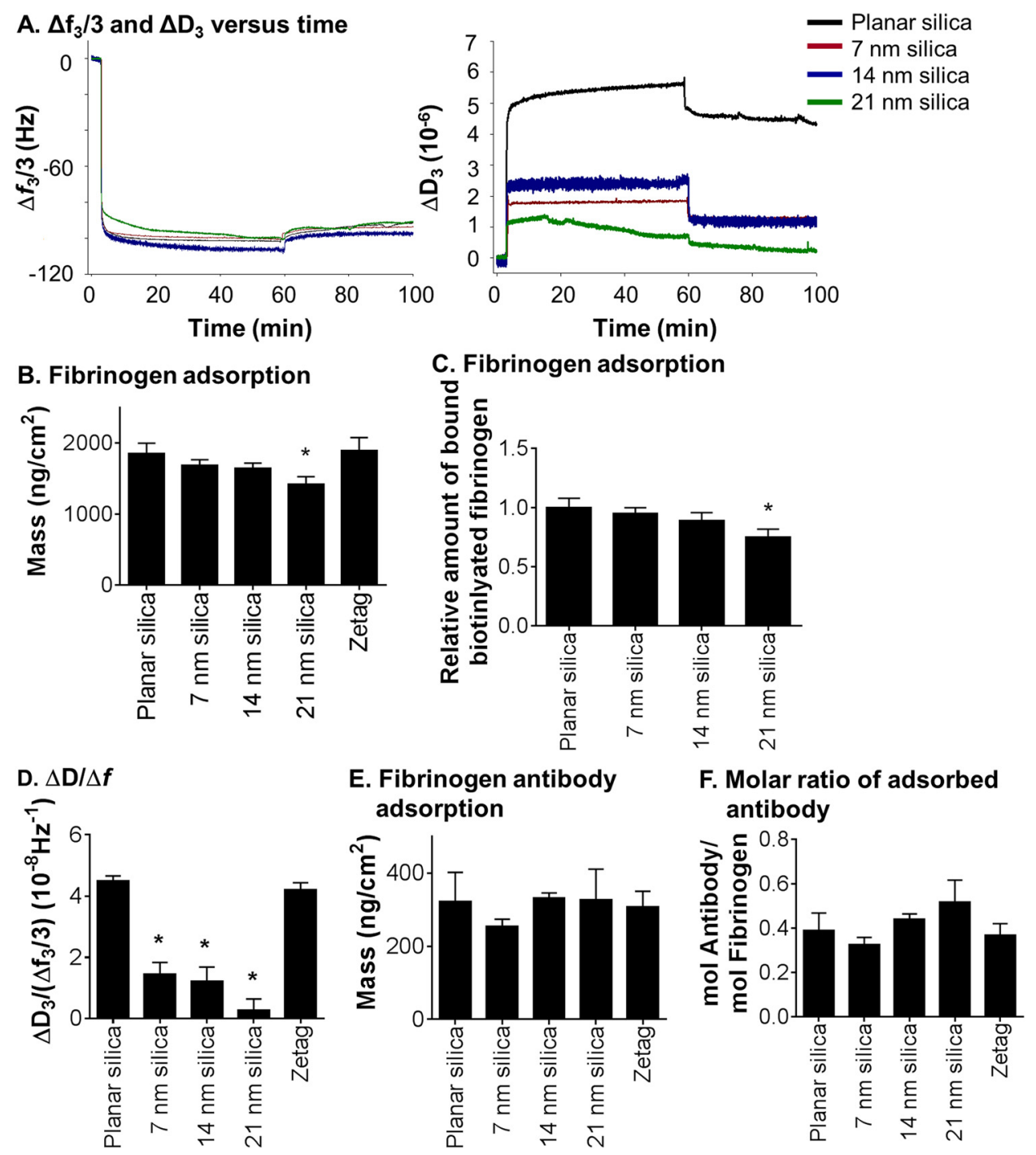

FIG. 2. (a) Comparison of fibrinogen adsorption profiles determined by QCM-D as monitored by $\Delta f_{3} / 3$ and $\Delta \mathrm{D}_{3}$; (b) mass adsorption of fibrinogen onto each of the surfaces as determined by Voigt modeling of QCM-D data and adjusted for surface area as determined by AFM; (c) relative amount of biotinylated fibrinogen bound to each of the nanorough silica surfaces compared to planar silica adjusted for surface area as determined by AFM; (d) dissipation vs frequency ratio $(\Delta \mathrm{D} / \Delta f)$ of QCM-D data presented for the 3rd overtone; (e) mass of antibody adsorbed to each of the fibrinogen coated surfaces as determined by Voigt modeling of the QCM-D data and adjusted for surface area as determined by AFM; and (f) moles of fibrinogen antibody bound per mole of fibrinogen on each of the surfaces as determined by QCM-D. Error bars: SD $(n=3)$. * indicated significant differences $(p<0.05)$ compared to planar silica as determined by a two-way ANOVA.

topography. These surface nanofeatures were hypothesized to lead to fibrinogen being adsorbed in a predominantly endon configuration, which led to a more closely packed protein layer. This same observation has been reported for platinum surfaces with nanorough surface topography that was also generated by the GLAD technique. ${ }^{24}$ These studies investigated nanoscale surface roughnesses in the order of the $R_{r m s}$ values of $2-32 \mathrm{~nm}$ for the tantalum surfaces and $1.5-9 \mathrm{~nm}$ for the platinum surfaces. These are in the same order of magnitude as the roughness of the silica surfaces analyzed in the present study; however, the nanotopography profile was quite different for the nanorough surfaces generated using GLAD compared to the silica particle deposition technique used in this study. This indicated that surface topography, not just overall surface roughness, may explain the different fibrinogen binding mechanism observed in this study.
QCM-D measurements include water bound and/or hydrodynamically coupled to the adsorbed proteins. The difference between adsorbed fibrinogen mass estimates for QCM-D measurements and optical techniques, such as ellipsometry and optical waveguide lightmode spectroscopy, previously reported indicated that QCM-D measurements are a factor of between 2.8 and 3.2 larger than the optical techniques. ${ }^{25}$ The theoretical side-on monolayer coverage of fibrinogen is approximately $140 \mathrm{ng} / \mathrm{cm}^{2}$ while the close packed end-on monolayer is $1000 \mathrm{ng} / \mathrm{cm}^{2}$ (Ref. 25), which equates to approximately 420 and $3000 \mathrm{ng} / \mathrm{cm}^{2}$, respectively, for QCM-D measurements. The experimentally determined adsorbed fibrinogen estimates [Fig. 2(b)] indicated that fibrinogen was bound to all the surfaces in the range of $1500-2000 \mathrm{ng} / \mathrm{cm}^{2}$, consistent with fibrinogen adsorbed onto each of the surfaces in a mixture of end-on and side-on 
configurations. The relative amount of fibrinogen bound to each of the surfaces was analyzed by measuring the amount of adsorbed biotinylated fibrinogen to each of the silica surfaces and the values were adjusted for increased surface area on the nanorough surfaces compared to the planar silica [Fig. 2(c)]. There was significantly less fibrinogen adsorbed onto the $21 \mathrm{~nm}$ silica surface compared to the planar silica $(p<0.05)$, while there was no significant difference in the amount of fibrinogen bound to either the 7 or $14 \mathrm{~nm}$ silica surfaces compared to the planar silica, confirming the QCM$D$ results shown in Fig. 2(b).

Analysis of the ratio between $\Delta \mathrm{D}$ and $\Delta f$ has been shown to provide a qualitative measure of the rigidity of protein films ${ }^{26}$ and may infer structural changes in the protein layer and/or the extent of hydrodynamically bound water. ${ }^{27,28}$
Stable $\Delta \mathrm{D} / \Delta f$ values after protein adsorption and $\mathrm{PBS}$ rinses for the third overtone for fibrinogen adsorbed onto each of the silica nanorough surfaces were lower compared to the planar silica, which indicated that the fibrinogen formed a more rigid layer on the nanorough surfaces compared to planar silica [Fig. 2(d)]. There was no significant difference between the $\Delta \mathrm{D} / \Delta f$ values for the Zetag coated surface and planar silica [Fig. 2(d)]. The difference in $\Delta \mathrm{D} / \Delta f$ values for the nanorough surfaces and the planar silica was primarily due to the larger $\Delta \mathrm{D}$ values observed for fibrinogen adsorption on the planar silica with $\Delta \mathrm{D}$ of $1 \times 10^{-6}$ for fibrinogen adsorbed onto $21 \mathrm{~nm}$ nanorough silica. Surfaces that are rough can entrap liquid within surface cavities ${ }^{29,30}$ and have been shown to result in an excess liquid phase response in the QCM-D, primarily observed as a larger magnitude decrease in $f$ (Ref. 31)
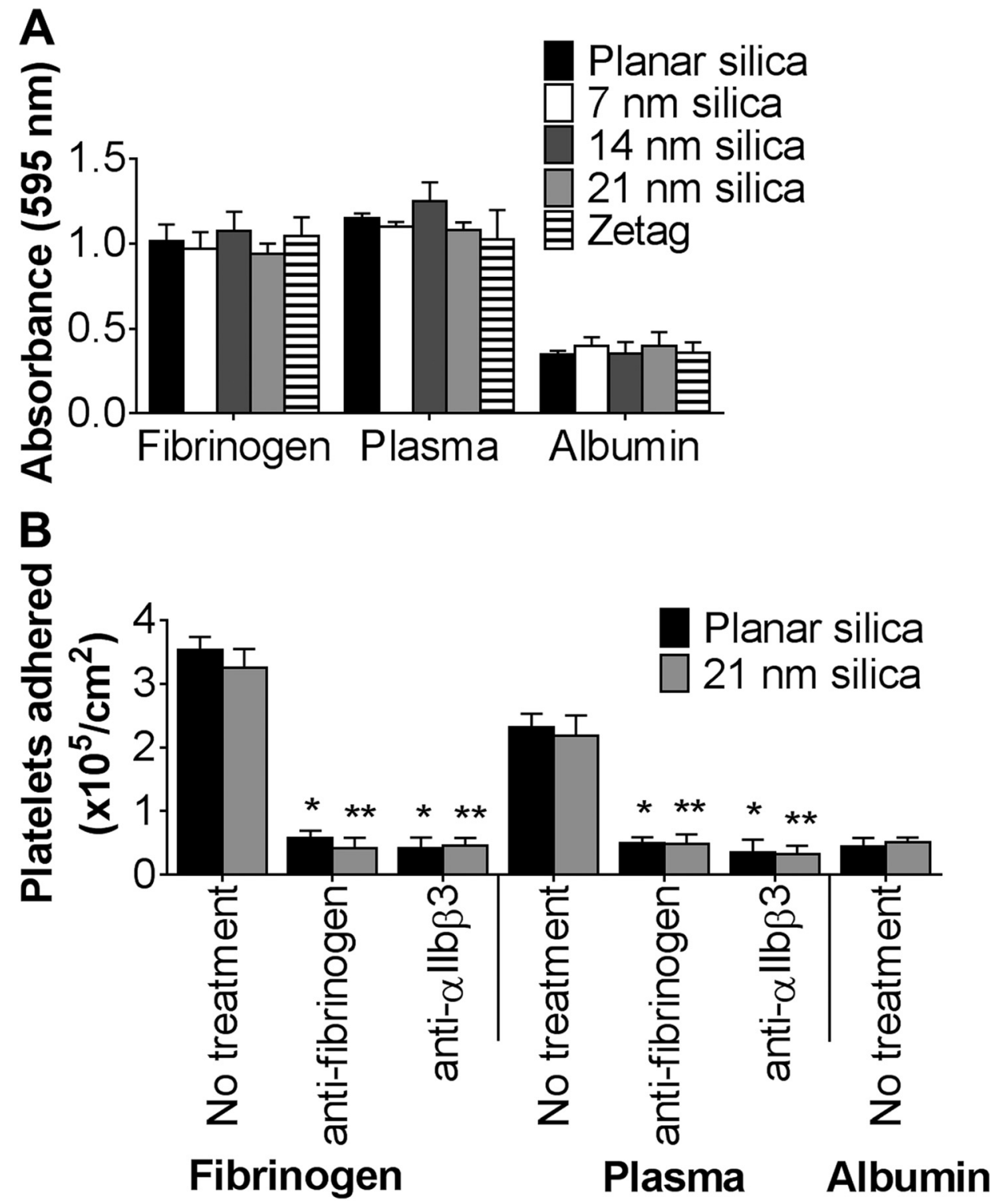

FIG. 3. Platelet adhesion to fibrinogen, plasma, or albumin coated planar silica, nanorough silica, or Zetag coated surfaces determined by (a) LDH assay and (b) analysis of fluorescence microscope images of platelets exposed to protein coated surfaces and stained for the presence of actin. Data presented have been corrected for changes in surface area induced by the surface coatings. Error bars: SD $(\mathrm{n}=3)$. * indicated significant differences $(p<0.05)$ compared to untreated planar silica and ** indicated significant differences $(p<0.05)$ compared to untreated $21 \mathrm{~nm}$ silica as determined by a two-way ANOVA. 
accompanied by little change in D compared with smooth surfaces. The liquid "trapped" within the surface structure can be treated as a rigid mass as long as the lateral scale of the surface roughness is less than the penetration depth. ${ }^{32}$ This phenomenon would result in smaller $\Delta \mathrm{D} / \Delta f$ values for rough surfaces compared to the planar silica. Although smaller $\Delta \mathrm{D} /$ $\Delta f$ values were observed in this study for the nanorough surfaces compared to the planar silica, larger decreases in $\mathrm{f}$ were not observed in this study for the nanorough surfaces compared to the planar silica. This indicated that water trapped in the surface features was not responsible for the stiffer protein layers on the nanorough surfaces compared to the planar silica, but likely to be changes in the orientation, conformation and/or hydration state of the proteins.

Structural changes in the fibrinogen adsorbed onto each of the surfaces was also investigated using QCM-D by measuring the amount of fibrinogen antibody that bound to the fibrinogen adsorbed onto each of the surfaces and mass values were adjusted for the surface area as measured by AFM [Fig. 2(e)]. The fibrinogen antibody used binds to the platelet binding region of fibrinogen and hence was used to infer the structure of the adsorbed fibrinogen and its capacity to support platelet binding to the different surfaces. Each of the fibrinogen coated surfaces was found to support a similar level of antibody binding [Fig. 2(e)]. Non-specific antibody binding to the protein precoated surfaces was determined by measuring both the binding of the fibrinogen antibody to casein precoated surfaces and antialbumin antibody binding to the fibrinogen coated surfaces using the QCM-D. A maximum of $22 \mathrm{ng} / \mathrm{cm}^{2}$ of antibody was detected, indicating a low level of nonspecific antibody binding to the test surfaces. The molar ratio of the adsorbed fibrinogen antibody to the adsorbed fibrinogen for each of the surfaces indicated that was no significant difference in the amount of antibody bound to fibrinogen adsorbed onto the nanorough silica surfaces and Zetag coated surface compared to planar silica [Fig. 2(f)]. This provides an indication that surface topography may not change the capacity of the adsorbed fibrinogen to bind platelets on the different surfaces.

\section{Platelet adhesion}

Platelet adhesion to protein precoated nanorough silica surfaces was investigated to determine whether stochastic surface nanotopography affected the activity of the adsorbed proteins. The number of platelets adhered to protein precoated nanorough silica surfaces was not affected by the surface nanotopography when compared to planar silica [Fig. 3(a)]. Albumin precoated surfaces supported less platelet adhesion compared with fibrinogen or plasma precoated surfaces confirming previous reports that albumin minimizes platelet adhesion. ${ }^{33}$ This phenomenon was also observed for albumin coated nanorough surfaces, although the adhesion of platelets to each of the albumin coated surfaces would indicate that albumin does not completely inhibit platelet adhesion.

Albumin coated polystyrene has also been reported to support nonspecific platelet adhesion. ${ }^{34}$ As each of the nanorough silica surfaces supported the same level of platelet adhesion, only the $21 \mathrm{~nm}$ surface was taken forward for further analysis. The number of platelets adhered to fibrinogen coated planar silica and $21 \mathrm{~nm}$ silica was significantly $(p<0.05)$ inhibited by the addition of antibodies that bound to either the platelet binding site on fibrinogen (clone $2 \mathrm{C} 2$ G7) or antibodies that bound to the $\alpha \operatorname{IIb} \beta 3$ integrin on the surface of platelets [Fig. 3(b)]. Surface topography had no effect on the number of platelets adhered to the different fibrinogen precoated surfaces [Fig. 3(a)] supporting the finding that although there was a reduced amount of fibrinogen adsorbed to the $21 \mathrm{~nm}$ silica surface, there was no significant difference in the amount of fibrinogen antibody that bound to the fibrinogen adsorbed onto each of the surfaces [Fig. 2(d)]. These data suggested that the orientation and hydration of adsorbed fibrinogen on each of the surfaces had no effect on the level of platelet adhesion.

Analysis of the morphology of platelets adhered to protein coated surfaces indicated that platelets adhered to fibrinogen coated planar silica with a spread morphology and well-developed actin fibers at the leading edge of the cell membrane [Fig. 4(a i)]. In contrast, platelets adhered to fibrinogen coated $21 \mathrm{~nm}$ silica surfaces exhibited a rounded

\section{A. Planar Silica B. 21nm Silica} (i) Fibrinogen

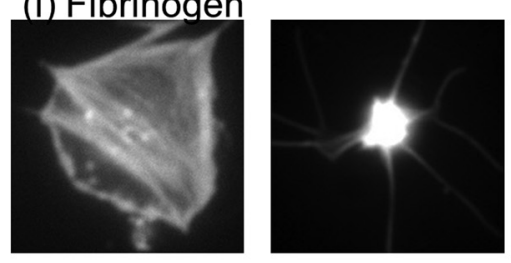

(ii) Plasma

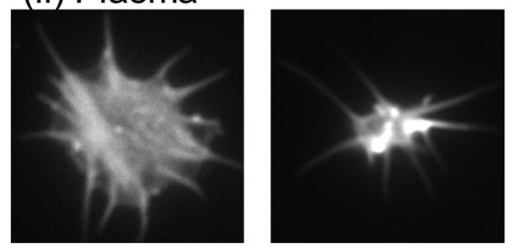

(iii) Albumin

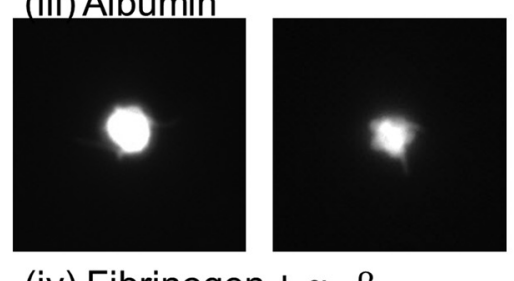

(iv) Fibrinogen $+\alpha_{\| b} \beta_{3}$

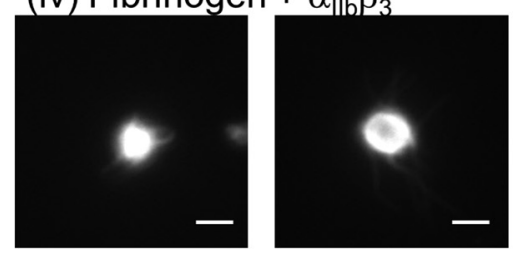

FIG. 4. Fluorescence microscope images of platelets exposed to (a) planar silica or (b) $21 \mathrm{~nm}$ silica precoated with (i) fibrinogen, (ii) plasma, (iii) albumin, or (iv) fibrinogen when platelets were pretreated with anti- $\alpha_{\mathrm{IIb}} \beta_{3}$ integrin antibody and stained for their actin cytoskeleton. Scale bar represents $2 \mu \mathrm{m}$. 
morphology with radial protrusions containing actin that was not filamentous [Fig. 4(b i)]. Similarly, platelets adhered to plasma coated $21 \mathrm{~nm}$ silica exhibited a rounded morphology with radial protrusions containing actin that was not filamentous [Fig. 4(b ii)] while platelets adhered to plasma coated planar silica surfaces exhibited a more spread morphology with radial protrusions [Fig. 4(a ii)]. Platelets adhered to albumin coated surfaces exhibited a rounded morphology with no apparent development of actin-rich stellate-shaped pseudopodia [Figs. 4(a) and 4(b iii)] and this same morphology was observed for platelets treated with anti- $\alpha \operatorname{IIb} \beta 3$ Fab fragment antibody and then exposed to fibrinogen coated surfaces (Figs. 4(a) and 4(b iv)]. Hence, although the level of platelet adhesion to the fibrinogen coated surfaces was the same, there were differences in the morphology of the attached platelets, indicating that surface nanotopography altered the platelet responses.

The $\Delta f$ and $\Delta \mathrm{D}$ versus time plots are shown for the albumin blocking step following fibrinogen adsorption onto the surfaces and the platelet exposure step for planar silica [Fig. 5(a)] and $21 \mathrm{~nm}$ silica [Fig. 5(b)]. The addition of albumin resulted in a decrease in $f$ and an increase in D for each of the surfaces. Exposure of platelets to albumin blocked fibrinogen on the planar silica resulted in a further decrease in $f$ and increase in $\mathrm{D}$ with close agreement between the third, fifth, and seventh overtones [Fig. 5(a)]. In contrast, platelets exposed to fibrinogen coated and albumin blocked $21 \mathrm{~nm}$ silica surfaces resulted in little change in $f$ over the measurement period that was accompanied by increases in $\mathrm{D}$ [Fig. 5(b)]. The $\Delta \mathrm{D}$ values for the fifth and seventh overtones were in good agreement with slightly higher $\Delta \mathrm{D}$ values recorded for the third overtone.

Typical $\mathrm{D} f$ plot for platelets interacting with fibrinogen surfaces are shown in Fig. 6(a) and the arrows indicate the time sequence of the data. The QCM-D responses for platelets adhering to fibrinogen coated planar silica and $21 \mathrm{~nm}$ silica surfaces were quite different from each other which indicated that platelets interacted differently with each of these surfaces, even though they all supported the same level of platelet adhesion [Figs. 3(a) and 3(b)]. The viscoelastic region on the $\mathrm{D} f$ plot is the region between a pure elastic mass response where $\Delta \mathrm{D}=0$ and a pure liquid viscositydensity change in the fluid above the crystal in the absence of surface binding [Fig. 6(a)]. ${ }^{29,35}$ Exposure of platelets to planar silica coated with fibrinogen resulted in $\mathrm{D} f$ plots that fell within the viscoelastic region and hence these interactions behaved as viscoelastic materials during the first 30 min. During the last $30 \mathrm{~min}$ of the experiment the $\mathrm{D} f$ responses deviated from the viscoelastic behavior as the platelets exhibited a greater level of energy dissipation above the sensor surface. The $\mathrm{D} f$ plots for platelets interacting with fibrinogen coated planar silica continued to exhibit decreases in $f$ and increases in $\mathrm{D}$ throughout the measurement period which was consistent with increased platelet surface contact and hence increased platelet volume being sensed throughout the measurement period. Coupled with this was the development of the actin cytoskeleton as shown by the spread
A. Planar silica

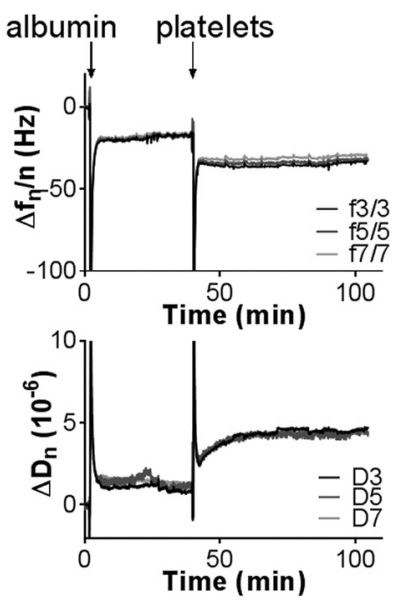

\section{B. $21 \mathrm{~nm}$ silica}
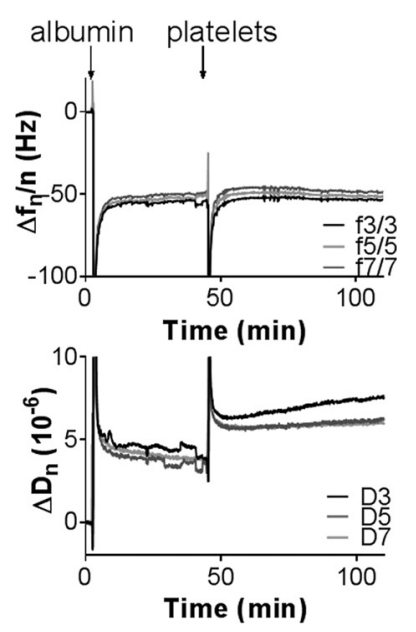

FIG. 5. $\Delta \mathrm{f}_{\mathrm{n}} / \mathrm{n}$ and $\Delta \mathrm{D}_{\mathrm{n}}$ measurements vs time for (a) planar silica and (b) $21 \mathrm{~nm}$ silica surfaces precoated with fibrinogen and exposed to albumin followed by platelet suspension. The arrows indicate the time of addition of albumin and platelets, respectively, while the surfaces were exposed to PBS prior to the addition of albumin. Data presented for the third, fifth, and seventh overtones.

morphology of platelets adhered to this surface [Fig. 4(a i)]. Hence, the deviation from viscoelastic behavior coincided with actin polymerization to form actin-rich radial protrusions. This phenomenon has been observed previously for many mammalian cells as active cell-surface contacts are formed and their cytoskeleton develops within 1-15 min after attachment to a surface. ${ }^{29,35-38}$ Interestingly, platelets exposed to fibrinogen coated planar silica did not cause any change in D throughout the second 30 min of exposure, but caused an increase in $f$. Positive $f$ shifts have been reported for colloidal particles that form point contacts with the resonator surface and have a high mass. ${ }^{39}$ When the particles only form point contacts with the resonator surface, the forces exerted by the resonating crystal do not move the particles; however, the particles exert a restoring force on the crystal which adds internal stiffness to the crystal, thereby increasing $f{ }^{40}$ Hence, changes in $f$ depend on the coupling strength, surface coverage, and inertial forces that are driven 


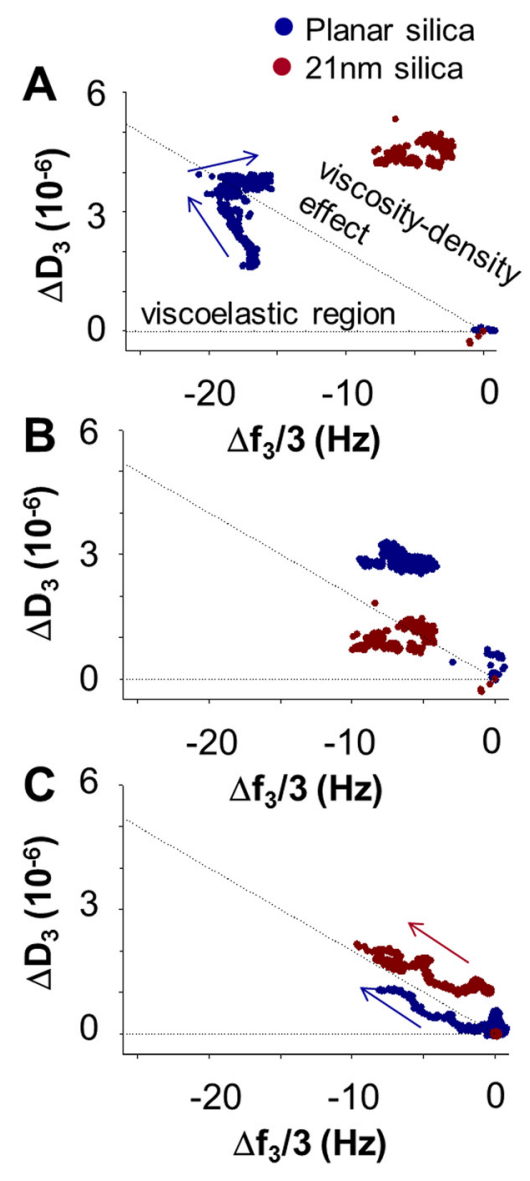

FIG. 6. $\mathrm{D} f$ plots for platelets exposed to (a) fibrinogen coated planar silica and $21 \mathrm{~nm}$ silica, (b) albumin coated planar silica and $21 \mathrm{~nm}$ silica, or (c) platelets preincubated with anti- $\alpha \operatorname{IIb} \beta 3$ antibody and then exposed to fibrinogen coated planar silica and $21 \mathrm{~nm}$ silica monitored over a period of $1 \mathrm{~h}$ at $37^{\circ} \mathrm{C}$. The arrows indicate the time course of the data points. The pure elastic mass and viscosity-density responses are indicated by the dashed lines.

by the properties of the adsorbed layer. The positive $f$ shifts observed in this study for platelets interacting with planar silica are likely to be due to changes in the viscoelastic properties of the adhered platelet layer. Positive $f$ shifts have been reported when the ratio between viscosity and elasticity of a cell layer increases. ${ }^{40,41}$ These mechanical changes in the cell layer are largely driven by changes in the cytoskeleton and have been previously reported for fibroblast cells interacting with serum coated oxidized polystyrene ${ }^{37}$ as well as epithelial cells. ${ }^{42}$

The $\mathrm{D} f$ plot for platelets interacting with fibrinogen coated $21 \mathrm{~nm}$ silica surfaces was quite different compared to the $\mathrm{D} f$ plot for platelets interacting with planar silica [Fig. 6(a)]. After an initial decrease in $f$ to $-3 \mathrm{~Hz}$ and an increase in $\mathrm{D}$ to $4.5 \times 10^{-6}$, there was little change in both $f$ and $\mathrm{D}$ throughout the measurement period. This indicated that there was a low level of platelet-surface contact throughout the measurement period that was consistent with the rounded morphology of platelets exposed to this surface [Fig. 4(b i)]. Throughout the measurement period the platelet response to this material fell outside the viscoelastic region with high D values, almost no change in $f$ and little change in these measurements over the experimental period. High $\Delta \mathrm{D} / \Delta f$ ratios have been observed when there is a weak coupling between the resonator and the bound layer, which is indicative that the platelets were loosely bound to the $21 \mathrm{~nm}$ silica surface. $^{43,44}$ This indicated that the contact strength between platelets and fibrinogen coated surfaces was weaker for the nanorough surfaces than the planar silica.

The response of platelets to each of the albumin coated surfaces was also quite different and indicated that surface topography played a role in the QCM responses [Fig. 6(b)]. The $\mathrm{D} f$ plot for platelets exposed to albumin coated surfaces showed little change in measurements throughout the experiment after the initial platelet-surface contact that resulted in shifts in $f$ approximately $-5 \mathrm{~Hz}$ each. The difference between the platelets exposed to the different albumin coated surfaces is evident in $\Delta \mathrm{D}$ as platelets exposed to albumin coated planar silica resulted in a maximum $\Delta \mathrm{D}$ of $1.8 \times 10^{-6}$ while platelets exposed to albumin coated $21 \mathrm{~nm}$ silica resulted in a maximum $\Delta \mathrm{D}$ of $3.7 \times 10^{-6}$. Additionally, $\Delta \mathrm{D}$ has been reported to be considerably larger for loosely adhered particles in contact with the resonator surface compared to a homogeneous film with the same thickness and viscoelastic properties. ${ }^{40}$ Hence, $\Delta \mathrm{D} / \Delta f$ increases with weaker contacts between the platelets and the protein coated surfaces as observed in this study for the $21 \mathrm{~nm}$ silica surfaces which supported weaker platelet-surface point contacts than planar silica, irrespective of adsorbed proteins.

Preincubation of the platelets with anti- $\alpha \operatorname{IIb} \beta 3$ antibody followed by exposure to fibrinogen coated surfaces presented $\mathrm{D} f$ responses that fell within the viscoelastic region for planar silica [Fig. 6(c)]. Platelets exposed to fibrinogen coated planar silica displayed decreases in $f$ and increases in $\mathrm{D}$ throughout the measurement period, that closely followed the viscosity-density relationship between $\Delta \mathrm{D}$ and $\Delta f$. The response of platelets preincubated with anti- $\alpha \mathrm{IIb} \beta 3$ antibodies and exposed to fibrinogen coated planar silica resulted in final $\Delta \mathrm{D}$ and $\Delta f$ values of $1 \times 10^{-6}$ and $-8 \mathrm{~Hz}$, respectively, indicating that only low levels of platelet cell membrane focal contacts were coupled to the resonator surface at the end of the measurement period. Similarly, platelets treated with anti- $\alpha \mathrm{IIb} \beta 3$ antibodies exposed to $21 \mathrm{~nm}$ silica surfaces caused decreases in $f$ and increases in D [Fig. 6(c)] throughout the measurement period that closely followed the viscosity-density relationship with final $\Delta \mathrm{D}$ and $\Delta f$ values of $2.2 \times 10^{-6}$ and $-10 \mathrm{~Hz}$, respectively. Platelet interactions with surfaces analyzed by the QCM-D are not limited to irreversible platelet adhesion as transient platelet contacts are recorded and indicate that platelet-surface contact can occur even in the presence of anti- $\alpha \mathrm{IIb} \beta 3$ which does not allow the development of stable platelet-surface contacts such as integrin mediated adhesion.

Analysis of the $\Delta f$ and $\Delta \mathrm{D}$ responses from platelet interactions with fibrinogen coated surfaces cannot be interpreted by the Sauerbrey relationship due to the high D values obtained. The Voigt model assumes that the adsorbed layer is of uniform thickness and density, conserves its shape and does not flow. $^{45}$ While this model has limitations for 
A. Planar silica
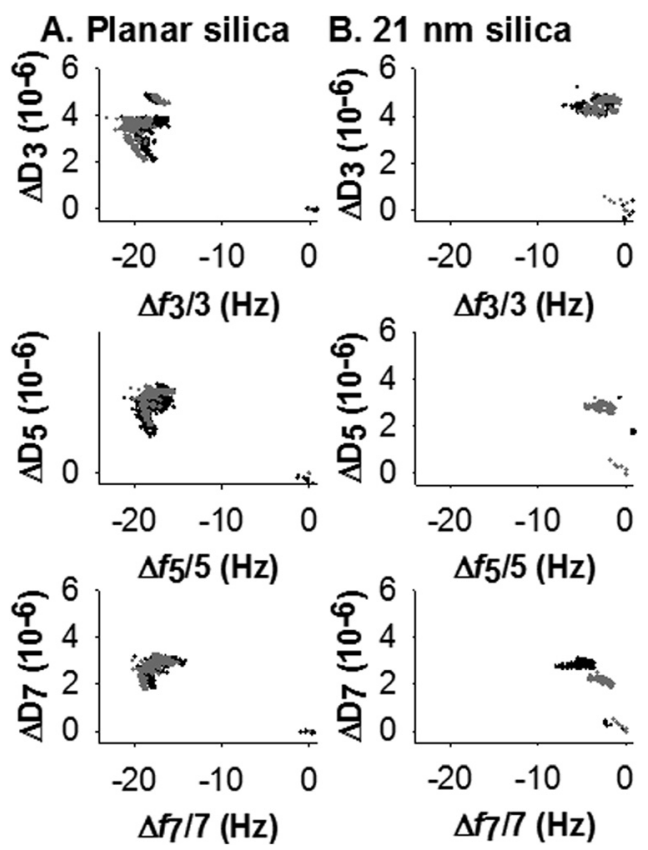

FIG. 7. Df plots platelets exposed to fibrinogen coated (a) planar silica and (b) $21 \mathrm{~nm}$ silica. Raw data (black) and Voigt fitted data (gray) presented for the third, fifth, and seventh overtones.

modeling platelet-surface interactions as the platelet layers observed in this study are heterogeneous, this model provided a good fit for the data obtained for platelets interacting with fibrinogen coated planar silica [Fig. 7(a)]. There is good agreement in the raw and fitted values between overtones for platelet interactions with fibrinogen coated planar silica indicating homogeneity in the platelet-surface interactions across the resonator surface for these coatings. Raw data for platelets exposed to fibrinogen coated $21 \mathrm{~nm}$ silica surfaces showed variation between the scaled overtones in the $\Delta \mathrm{D}$ values with the third overtone exhibiting higher values than the fifth and seventh overtones, which indicated heterogeneity in the platelet-surface interactions across the resonator surface [Figs. 5(b) and 7(b)]. The Voigt model provided a fit of the raw data and also displayed heterogeneity in the $\Delta \mathrm{D}$ values (Fig. 7). The Voigt model fit for the mass of platelets bound to fibrinogen coated planar silica was approximately $41 \mu \mathrm{g} / \mathrm{cm}^{2}$. Using the platelet density and volume as $1.0712 \mathrm{~g} / \mathrm{cm}^{3}$ and $7 \times 10^{-12} \mathrm{~cm}^{3}$, respectively, approximately $2.3 \times 10^{7}$ platelets in a spherical morphology can completely cover the surface of a QCM crystal, which equates to approximately $1.7 \times 10^{5} \mathrm{ng} / \mathrm{cm}^{2}$. Approximately $26 \%$ of the surface area of fibrinogen coated planar silica was calculated to be covered by platelets from the Voigt model, which is in close agreement with $32 \pm 6 \%$ of the surface covered by platelets as determined by analysis of fluorescence microscope images of actin stained platelets. The Voigt model, however, overestimated the proportion of the surface covered by platelets on fibrinogen coated $21 \mathrm{~nm}$ silica at approximately $20 \%$ while image analysis indicated that $10 \pm 3 \%$ of the surface was covered by platelets. This discrepancy could be due to the QCM-D measuring transient cell-surface interactions that were not observed after fixation and imaging of the platelets. Together these data further supported that platelet adhesion was altered on the $21 \mathrm{~nm}$ silica surface compared to the planar silica.

\section{SUMMARY AND CONCLUSIONS}

The present study has shown that stochastically nanorough silica surfaces were able to support the same level of fibrinogen adsorption, except for the roughest surface analyzed with a $R_{r m s}$ of $15 \mathrm{~nm}$, which supported significantly less fibrinogen adsorption, compared to planar silica. Fibrinogen was found to adsorb in a more rigid layer on all the nanorough surfaces compared to the planar silica; however, all surfaces supported the same level of platelet adhesion. Platelets bound to fibrinogen coated nanorough silica surfaces were rounded in morphology with few actin-rich radial protrusions while platelets bound to planar silica were spread with a well-developed actin cytoskeleton. QCM-D analysis indicated that platelets were more loosely adhered to the nanorough surfaces compared to the planar silica. Unique QCM-D responses were found for platelets exposed to each of the protein coated surfaces and indicated that the interactions are unique for each cell adhesive protein and surface. The Voigt model provided a realistic fit of the QCM-D data that correlated well with the microscopy images of adhered platelets. Together these data provide additional information about the dynamics of platelet-biomaterial interactions and demonstrate that surface nanotopography can affect cell-surface interactions that may have application in understanding platelet-material interactions for the development of blood contacting devices.

\section{ACKNOWLEDGMENT}

The authors would like to acknowledge technical assistance from Romana Tomic from the Graduate School of Biomedical Engineering, UNSW.

${ }^{1}$ B. G. Cousins, P. J. Doherty, R. L. Williams, J. Fink, and M. J. Garvey, J. Mater. Sci. 15, 355 (2004).

${ }^{2}$ E. T. den Braber, J. E. de Ruijter, L. A. Ginsel, A. F. von Recum, and J. A. Janssen, J. Biomed. Mater. Res. 40, 291 (1998).

${ }^{3}$ M. S. Lord, M. Foss, and F. Besenbacher, Nano Today 5, 66 (2010).

${ }^{4}$ M. S. Lord, B. G. Cousins, P. J. Doherty, J. M. Whitelock, A. Simmons, R. L. Williams, and B. K. Milthorpe, Biomaterials 27, 4856 (2006).

${ }^{5}$ M. B. Hovgaard, K. Rechendorff, J. Chevallier, M. Foss, and F. Besenbacher, J. Phys. Chem. B 112, 8241 (2008).

${ }^{6}$ T. J. Webster, L. S. Schadler, R. W. Siegel, and R. Bizios, Tissue Eng. 7, 291 (2001).

${ }^{7}$ L. B. Koh, I. Rodriguez, and S. S. Venkatraman, Biomaterials 31, 1533 (2010).

${ }^{8}$ W. B. Tsai, Y.-C. Ting, J.-Y. Yang, J.-Y. Lai, and H.-L. Liu, J. Mater. Sci. 20, 1367 (2009).

${ }^{9}$ D. S. Sutherland, M. Broberg, H. Nygren, and B. Kasemo, Macromol. Biosci. 1, 270 (2001).

${ }^{10}$ M. Hulander, A. Lundgren, L. Faxälv, T. L. Lindahl, A. Palmquist, M. Berglin, and H. Elwing, Colloids Surf., B 110, 261 (2013).

${ }^{11}$ B. M. C. Chan and J. L. Brash, J. Colloid Interface Sci. 82, 217 (1981).

${ }^{12}$ J. N. Lindon, G. McManama, L. Kushner, E. W. Merrill, and E. W. Salzman, Blood 68, 355 (1986).

${ }^{13}$ P. Schaaf and P. Dejardin, Colloids Surf., A 31, 89 (1988). 
${ }^{14}$ R. L. Williams, D. J. Wilson, and N. P. Rhodes, Biomaterials 25, 4659 (2004).

${ }^{15}$ B. Savage and Z. M. Ruggeri, J. Biol. Chem. 266, 11227 (1991).

${ }^{16}$ R. Barbucci, S. Lamponi, and A. M. Aloisi, J. Biomed. Mater. Res. 46, 186 (1999).

${ }^{17}$ W.-B. Tsai, J. M. Grunkemeier, and T. A. Horbett, J. Biomed. Mater. Res. A 67A, 1255 (2003).

${ }^{18}$ M. W. Mosesson, K. R. Siebenlist, and D. A. Meh, Ann. N.Y. Acad. Sci. 936, 11 (2001).

${ }^{19}$ T. Sun, H. Tan, D. Han, Q. Fu, and L. Jiang, Small 1, 959 (2005).

${ }^{20}$ C. J. Nonckreman, S. Fleith, P. G. Rouxhet, and C. C. Dupont-Gillain, Colloids Surf., B 77, 139 (2010).

${ }^{21}$ Y. Tamada, E. A. Kulik, and Y. Ikado, Biomaterials 16, 259 (1995).

${ }^{22}$ M. S. Lord, B. Cheng, S. J. McCarthy, M. Jung, and J. M. Whitelock, Biomaterials 32, 6655 (2011).

${ }^{23}$ K. Rechendorff, M. B. Hovgaard, M. Foss, V. P. Zhdanov, and F. Besenbacher, Langmuir 22, 10885 (2006).

${ }^{24}$ A. Dolatshahi-Pirouz, C. P. Lennisi, S. Skeldal, M. Foss, J. Chevallier, V. Zachar, P. Andreasen, K. Yoshida, and F. Besenbacher, Nanotechnology 20, 095101 (2009).

${ }^{25}$ F. Höök et al., Colloids Surf., B 24, 155 (2002).

${ }^{26}$ F. Höök, M. Rodahl, B. Kasemo, and P. Brzezinski, Proc. Natl. Acad. Sci. U.S.A. 95, 12271 (1998).

${ }^{27}$ F. Höök, M. Rodahl, P. Brzezinski, and B. Kasemo, Langmuir 14, 729 (1998).

${ }^{28}$ A. Dolatshahi-Pirouz, S. Skeldal, M. B. Hovgaard, T. Jensen, M. Foss, J. Chevallier, and F. Besenbacher, J. Phys. Chem. C 113, 4406 (2009).

${ }^{29}$ K. A. Marx, Biomacromolecules 4, 1099 (2003).
${ }^{30}$ L. A. Theisen and S. J. Martin, Anal. Chem. 76, 796 (2004).

${ }^{31}$ G. McHale and M. I. Newton, J. Appl. Phys. 95, 373 (2004).

${ }^{32}$ S. J. Martin, Faraday Discuss. 107, 463 (1997).

${ }^{33}$ K. Kottke-Marchant, J. M. Anderson, Y. Umemura, and R. E. Marchant, Biomaterials 10, 147 (1989).

${ }^{34}$ W. B. Tsai, J. M. Grunkemeier, and T. A. Horbett, J. Biomed. Mater. Res. 44, 130 (1999).

${ }^{35}$ T. Zhou, K. A. Marx, M. Warren, H. Schulze, and S. J. Braunhut, Biotechnol. Progr. 16, 268 (2000).

${ }^{36}$ M. S. Lord, C. Modin, M. Foss, M. Duch, A. Simmons, F. S. Pedersen, F. Besenbacher, and B. K. Milthorpe, Biomaterials 29, 2581 (2008).

${ }^{37}$ M. S. Lord, C. Modin, M. Foss, M. Duch, A. Simmons, F. S. Pedersen, B. K. Milthorpe, and F. Besenbacher, Biomaterials 27, 4529 (2006).

${ }^{38}$ L. M. Waples, O. E. Olorundare, S. L. Goodman, Q. J. Lai, and R. M. Albrecht, J. Biomed. Mater. Res. 32, 65 (1996).

${ }^{39}$ E. Vittorias, M. Kappl, H. Butt, and D. Johannsmann, Powder Technol. 203, 489 (2010).

${ }^{40}$ K. K. Kanazawa, Faraday Discuss. 107, 77 (1997).

${ }^{41}$ K. A. Marx, T. Zhou, A. Montrone, H. Schulze, and S. J. Braunhut, Biosens. Bioelectron. 16, 773 (2001).

${ }^{42}$ C. G. Marxer, M. C. Coen, T. Greber, U. F. Greber, and L. Schlapbach, Anal. Bioanal. Chem. 377, 578 (2003).

${ }^{43}$ D. Johannsmann, I. Reviakine, E. Rojas, and M. Gallego, Anal. Chem. 80, 8891 (2008).

${ }^{44}$ E. Tellechea, D. Johannsmann, N. F. Steinmetz, R. P. Richter, and I. Reviakine, Langmuir 25, 5177 (2009).

${ }^{45}$ M. V. Voinova, M. Rodahl, M. Jonson, and B. Kasemo, Phys. Scr. 59, 391 (1999). 